\title{
MULTILATERALITATEA CONFLICTUALITĂŢII DIN PALESTINA - ISTORIC, PREZENT ȘI TENDINȚE
}

Dr. Mirela ATANASIU*

Palestina reprezintă pământ istoric, locuit deopotrivă de evrei și de arabi, „, mărul discordiei” pentru cele două comunități etnice încă de la stabilirea lor in acest teritoriu. Din cauza acestui antagonism, de-a lungul timpului, regiunea Orientului Mijlociu a găzduit o multilateralitate conflictuală generată de o serie de factori (istorici, etnici, naționali și religioși), care în prezent se manifestă în trei dispute subsecvente: arabo-israeliană, israeliano-palestiniană și religioasă.

Disputa socială a fost generată inițial de neînțelegerile intercomunitare dintre arabi și evrei, în teritoriul mandatului britanic al Palestinei și a degenerat în seria de războaie dintre Israel și statele arabe, disputa politică a fost declanșată între arabii palestinieni și israelieni situați în teritoriile ocupate de Israel și a dus la un conflict armat deschis între Israel și Gaza, iar disputa religioasă, care le însoțește permanent pe celelalte două, este legată de reclamarea, în mod egal de evrei şi musulmani, atât a întregului teritoriu al acestui ținut istoric, cât și a Ierusalimului.

Lucrarea se dorește a fi o clarificare a ceea ce reprezintă regiunea istorică Palestina și a devenirii sale sub impactulconflictualității generate pe fondul dorinței de statalitate exprimată de evrei și arabi în același spațiu. In cele ce urmează, vor $f i$ prezentate unele aspecte care prezintă sursele istorice ale teritorialității, statalității și conflictualității în regiune, și formele actuale ale multilateralității conflictuale palestiniene, precum și latura conflictuală predominantă în perioada contemporană, cu accent pe dezvoltările din prima jumătate a anului 2021, dar şi unele tendințe care se preconizează în evoluția problemei palestiniene.

* Dr. Mirela ATANASIU este cercetător științific gradul II în cadrul Centrului de Studii Strategice de Apărare și Securitate din Universitatea Națională de Apărare „Carol I”, București. Email: atanasiu.mirela@yahoo.com 
Cuvinte-cheie: problema palestiniană; Gaza; Cisiordania; Israel; soluția cu două state.

\section{Palestina - spațiu geografic cu îndelungat istoric conflictual}

Studii ale unor arheologi susțin că în sursele documentare istorice (în special, inscripții abasside și monede) s-au făcut referințe la acest teritoriu sub numele „Filastin” încă din Epoca Bronzului Târziu (începând cu anul 1300 î.e.n.) ${ }^{1}$. Cei care au scris în antichitate despre teritoriul Palestinei s-au referit la acesta ca la biblicul „Peleshet” (Pământul Filistinilor) sau la teritoriul Israel². Ulterior, în secolul al V-lea î.e.n., „părintele istoriei” Herodot denumea Palestina ca fiind spaţiul geografic dintre Fenicia și Egipt, care cuprindea atât ținutul filistinilor, cât și Israelul (Figura nr. 1). La acest spațiu ne vom referi în continuare în lucrare atunci când folosim sintagma „Palestina istorică”.

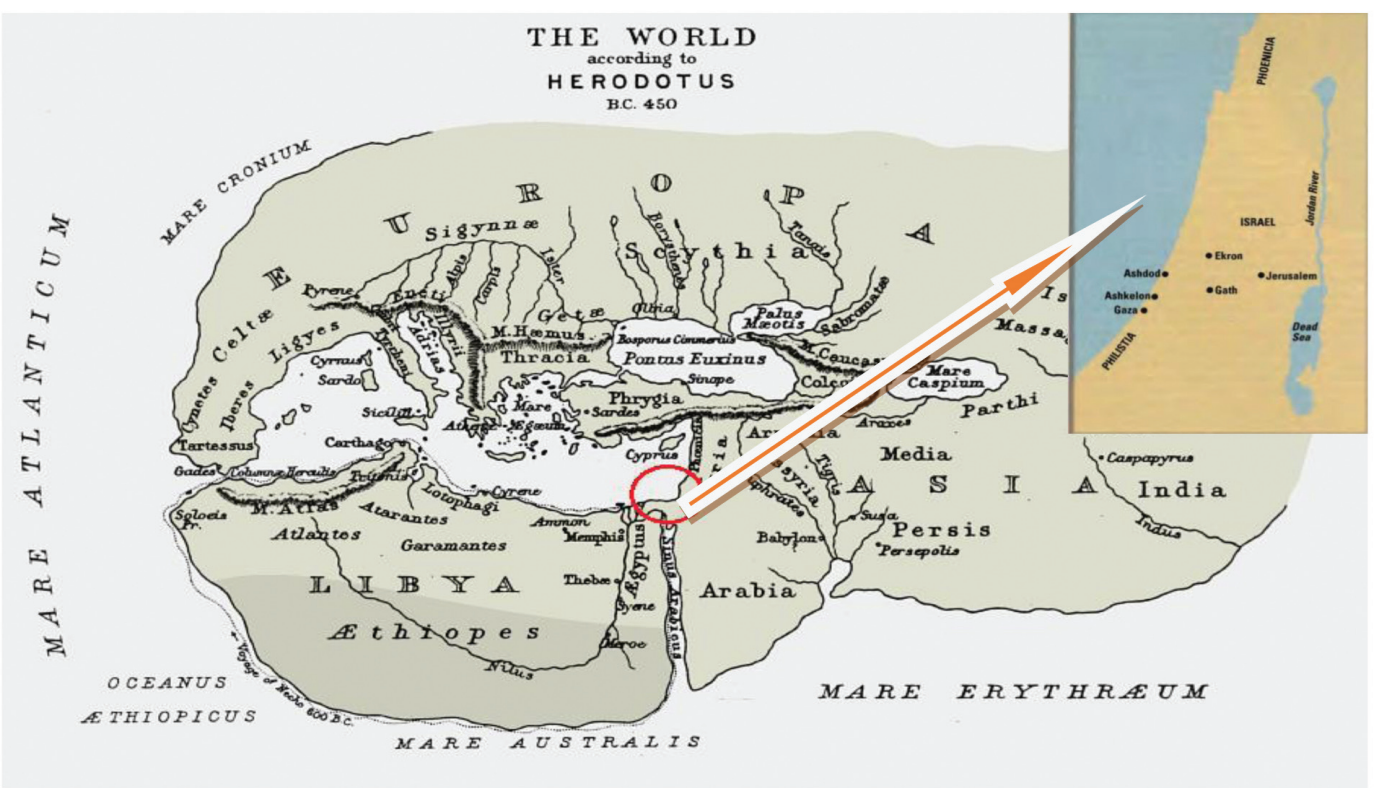

Figura nr. 1: Palestina în secolul al V-lea î.e.n. ${ }^{3}$

${ }^{1}$ De Nur Masalha, Palestine: A Four Thousand Year History, Zed Books Ltd., London, UK, 2018, p. 1 .

${ }^{2}$ David Jacobson, „When Palestine Meant Israel”, Biblical Archaeology Review, vol. 27, nr. 03, mai/iunie 2001, p. 45.

${ }^{3}$ Surse: ***, „Human landscapes and maps”, Panorama of the world, November 26, 2017, URL: https:/holylandmap.blogspot.com/2017/11/the-world-map-of-herodotus-in-shape-of.html; David Jacobson, „When Palestine Meant Israel”, Biblical Archaeology Review, Vol. 27, No. 03, mai/iunie 2001, URL: http://cojs.org/ when_palestine_meant_israel-_david_jacobson-_bar_27-03-_mayjun_2001/, accesate la 22.06.2021. 
De-a lungul istoriei, pe de o parte, evreii revendicau Palestina ca fiind „Pământul făgăduinței”, bazându-se pe narațiuni biblice și afirmând prezența lor neîntreruptă în acest teritoriu ${ }^{4}$. Pe de altă parte, arabii puneau sub semnul întrebării prezența neîntreruptă a evreilor și revendicau rădăcini arabe datând de peste un mileniús. Mai există și o altă categorie de etnici arabi, care susțineau (sau încă susțin) că sunt strămoși ai canaaniților ${ }^{6}$, stabiliți în teritoriu înaintea israeliţilor ${ }^{7}$. De altfel, în contextul conflictului etnico-religios dintre evrei și arabi, locurile și toponimele au căpătat o mare semnificație în eforturile de legitimare a dreptului istoric particular asupra acestui teritoriu.

În prezent, spaţiul Palestinei istorice reprezintă geografic regiunea Mediteranei de Est, cuprinzând părți din Israelul modern și teritoriile palestiniene ocupate de Israel din Fâșia Gaza (de-a lungul coastei Mării Mediterane) și Cisiordania (la vest de râul Iordan) ${ }^{8}$, inclusiv Ierusalimul de Est. Așadar, frontierele Palestinei istorice s-au schimbat de-a lungul timpului, în modernitate (începând cu instituirea mandatului britanic), ajungând să cuprindă efectiv teritoriile statelor actuale ale Israelului și Palestinei (care, deși recunoscută ca stat de o mare parte a comunității internaționale, are o statalitate nefinisată, fragmentată).

Crearea Palestinei ca entitate politică îşi are originea în pătrunderea triburilor israeliţilor în teritoriul său. Pe la 1250 î.e.n., sub conducerea lui Moise, se stabilesc în acest spațiu triburile israelite venite din Egipt, alături de triburile canaanite deja existente. Cam în acelaşi timp începe popularea coastelor mediteraneene ale Palestinei istorice de către triburile filistenilor ${ }^{9}$ şi se formează o alianţă a

4***, ,Genesis 15:18-21”, The Bible, URL: https://www.bible.com/ro/bible/1713/GEN.15.18-21, accesat la 22.06.2021.

${ }^{5}$ N.A.: Conform unor teorii, arabii i-au avut ca strămoși pe beduinii de acum o mie de ani. A se vedea: Werner Caskel, „The Bedouinisation of Arabia”, American Anthropologist, no. 56, 1954, p. 38; G.E. von Grunebaum, „The Nature of Arab Unity before Islam”, Arabica, no. 10, 1963, p. 12; Maxime Rodinson, Islam et capitalisme. Éditions du Seuil, Paris, 1966, p. 15.

${ }^{6}$ N.A.: Canaaniții sunt strămoșii palestinienilor care s-au stabilit în Canaan, în anul 3000 î.e.n. Între 1200 și 975 î.e.n., „,popoarele mării” s-au stabilit pe Coasta Canaanului devenind cunoscuți sub numele de filisteni. A se vedea: Alex Shalom, Stephen Rosskamm Shalom, „The Palestinian question", Harper's Magazine, decembrie 2001, p. 87.

${ }^{7}$ N.A.: Israeliții sunt strămoșii etnici din care provin evreii și samaritenii moderni. A se vedea: Peidong Shen, Tal Lavi et all, ,Reconstruction of Patrilineages and Matrilineages of Samaritans and Other Israeli Populations From Y-Chromosome and Mitochondrial DNA Sequence Variation", Human Mutation, Wiley-Liss Inc., No. 24, 2004, pp. 248-260.

8 ***, „Palestine”, Britannica, 25 iunie 2021, URL: https://www.britannica.com/place/Palestine, accesat la 22.06.2021.

${ }^{9}$ N.A.: Filistenii (în latină palaestina) sunt populație antică, de origine indo-europeană, stabilită între secolele XIII-XI î.e.n. pe coasta sud-estică a Mării Mediterane. Numele latin s-a impus în epoca romană asupra întregii zone, devenind Palestina. A se vedea: ***, „Filistina antică, Palestina”, Israel și Palestina, URL: https://sites.google.com/site/israelsipalestinaorigini/ filistina-antica-palestina, accesat la 01.06.2021. 
oraşelor-stat Aşdad, Aşchelon, Ecron, Gaza şi Gat, situate între Tel Avivul actual și Fâşia Gaza. ${ }^{10}$ În continuare, în secolul al XI-lea î.e.n., pentru a înlătura pericolul cauzat de puternicele presiuni exercitate de popoarele migratoare, se constituie Regatul Israel.

În secolul al X-lea î.e.n., Regele David, din tribul iudeilor, uneşte cele două entităţi statale existente la acea vreme - Iuda şi Israel - şi cucereşte Ierusalimul, pe care îl transformă în capitala religioasă şi politică a noului stat. Dar entitatea politică creată pe teritoriul Palestinei istorice nu rezistă mult, astfel încât, după moartea regelui Solomon, în 926 î.e.n., se divide din nou în Israel și Iuda ${ }^{11}$. Ulterior, cele două entităţi statale au evoluat în paralel, relațiile dintre ele fiind marcate de îndelungate războaie.

După ce, pentru circa două secole (539-332 î.e.n.), întreaga Palestină devine parte a Imperiului Persan, începând din anul 332 î.e.n., aceasta intră sub dominaţia lui Alexandru cel Mare şi inclusă în Imperiul Macedonean creat de acesta. Ulterior, au urmat o serie de alte dominații - romană, din anul 66 î.e.n. până în 313 e.n., când este înlocuită de cea bizantină -, musulmană timpurie (637-1098), cruciată catolică $(1099-1291)^{12}$, mamelucă $(1291-1517)^{13}$, otomană $(1517-1918)^{14}$, britanică (Marea Britanie și Liga Națiunilor au creat Mandatul Palestinian ${ }^{15}$ ca entitate statală care a funcționat între 1920 și 1948). Așadar, în termeni politici, regiunea istorică Palestina, în parte sau în totalitate, a constituit în cea mai mare perioadă o provincie în cadrul unui mare imperiu (doar rareori și pentru perioade scurte, ea formând o unitate politică independentă).

În anii 1880, comunitatea evreilor palestinieni se ridica la 3\% din populaţia totală și nu aspira să construiască un stat evreiesc modern în Palestina, aceasta fiind o idee emisă de britanici în Declaraţia Balfour din 1917, în care aceștia promiteau că vor sprijini ,înființarea în Palestina a unui stat național pentru poporul evreu"16. Mai mult, anterior, în 1915, Marea Britanie promisese lui Hussein, Șharrif-ul din

\footnotetext{
${ }^{10}$ Aren M. Maeir, „The Philistines and Their Cities”, Bible Odyssey, URL: https://www.bibleodyssey. org/en/places/related-articles/philistines-and-their-cities, accesat la 02.06.2021.

11 ***, Marea istorie ilustrată a lumii, vol. I, Editura Litera Internaţional, Bucureşti, 2008.

${ }^{12}$ Malcolm Barber, ,The Challenge of State Building in the Twelfth Century: The Crusader States in Palestine and Syria", Reading Medieval Studies, XXXVI, University of Reading, 2010, pp. 7-22.

13 ***, „Mamluks”, Jewish Virtual Library, URL: https://www.jewishvirtuallibrary.org/mamluks, accesat la 28.06.2021.

$14 * * *$, Return to Timeline of Jewish History: Table of Contents, URL: Jewish Virtual Library, https://www.jewishvirtuallibrary.org/timeline-of-ottoman-empire-dominance-1500-1920, accesat la 28.06.2021.

15 ***, C. 529. M. 314. 1922. VI., Communiqué au Conseil et aux Membres de la Société, Mandate for Palestine, League of Nations, Geneve, 12 august 1922.

16 ***, „The Nakba did not start or end in 1948”, Al Jazeera, 23 May 2017, URL: https://www. aljazeera.com/features/2017/ 5/23/the-nakba-did-not-start-or-end-in-1948, accesat la 14.06.2021.
} 
Mecca, că va sprijini crearea unui imperiu arab independent sub conducerea sa în Palestina, în schimbul organizării unei revolte arabe împotriva Imperiului Otoman, aliatul Germaniei în război ${ }^{17}$. Așadar, teritoriul fusese promis de către britanici ambelor părți.

Între timp, pe baza promisiunii britanice către evrei și a contextului istoric potrivnic acestora în alte părți ale lumii, dar și încurajată de mișcarea sionistă ${ }^{18}$, imigraţia evreilor către Palestina s-a realizat masiv. În 1923, când comunitatea internaţională (Liga Națiunilor, la acel moment) i-a desemnat Marii Britanii, odată cu acordarea mandatului de control administrativ asupra Palestinei, sarcina de a înființa în acest teritoriu pentru evrei, un stat al lor, s-a declanșat disputa etnicoreligioasă între evrei și arabi.

În continuare, în 1947, prin demersurile iniţiate de Marea Britanie, ONU a propus ,o soluție cu două state” ${ }^{19}$, un plan de împărțire a Palestinei în două teritorii: unul alocat unui stat evreu independent și celălalt alocat unui stat arab independent, orașul Ierusalim fiind desemnat teritoriu internațional față de ambele state care urmau a fi create.

\section{Palestina modernă ${ }^{20}$, trei dispute - un teritoriu}

După emiterea propunerii ONU a soluției cu două state, două tipuri de tensiuni arabo-israeliene s-au declanșat în zonă: regionale, între evreii sioniști care doreau

\footnotetext{
${ }_{17}$ N.A.: Promisiunea a fost cuprinsă într-o scrisoare datată 24 octombrie 1915, de către Sir Henry McMahon, Înaltul Comisar britanic în Egipt, către Sharif-ul din Mecca, în ceea ce a devenit ulterior cunoscut sub numele de corespondență McMahon-Hussein. Sharif-ul din Mecca a presupus că promisiunea include Palestina. Detalii în: Pauline Kollontai, Sue Yore, Sebastian Kim (eds.), The Role of Religion in Peacebuilding. Crossing the Boundaries of Prejudice and Distrust, Jessica Kinsley Publishers, London and Philadelphia, 2018, p. 251.

${ }^{18}$ Sionism, mișcare naționalistă evreiască care a avut ca scop crearea și sprijinul unui stat național evreu în Palestina, considerată de aceștia drept patria antică a evreilor. Zionism, The Editors of Encyclopaedia Britannica, URL: https://www.britannica.com/topic/Zionism, accesat la 16.06.2021. $19 * * *, A / R E S / 181(I I)$, Resolution adopted on the report of the ad hoc committee on the Palestinian question, UN General Assembly, 29 noiembrie 1947.

${ }^{20}$ N.A.: Așa cum am mai precizat în text, când ne referim la Palestina modernă ne referim strict la partea din spațiul istoric al Palestinei care a rămas încă în dispută între evrei şi arabi. Deci, eliminând teritoriile Palestinei istorice, care în prezent aparțin altor state (Siria, Iordania etc.), și nu fac subiectul temei analizate în acest material, ne referim la Palestina ca suprafață teritorială cuprinzând atât statul Israel, cât și actualele teritorii ocupate de acesta, respectiv Cisiordania (cu Israelul de Est) şi Gaza, pentru a fi mai ușor de făcut conexiunea cu teritoriul Palestinei istorice și a vedea transformările suferite atât de teritoriile disputate în diferite epoci istorice, cât şi modul de devenire a statalităţii în regiune. De altfel, actualele teritoriile ocupate este posibil să devină sau nu un stat în adevăratul sens al cuvântului, iar dacă devin un stat întreg, este posibil ca să nu se întindă exact pe amprenta teritorială pe care o ocupă astăzi, deoarece frontierele acestora sunt în mișcare, nefiind stabilite prin negocieri mutuale israeliano-palestiniene.
} 
constituirea unui stat al lor în acest spațiu al Orientului Mijlociu și statele arabe predominante în regiune; intercomunitare, între evrei și arabii palestinieni în spațiul comun al Mandatului Britanic al Palestinei. Ca urmare, după plecarea britanicilor în 1948, atunci când Israelul s-a autodeclarat stat independent, profitând de momentul prielnic, imediat s-a exacerbat prima latură a acestei conflictualități prin declanșarea primului război arabo-israelian între Israel și cinci dintre națiunile arabe din regiune (Iordania, Irak, Siria, Egipt și Liban), care susțineau comunitatea arabo-palestiniană în constituirea propriului stat în această regiune. Astfel, într-un an de lupte (19481949), până la încheierea unui armistițiu, Israelul cucerise aproximativ tot teritoriul Palestinei, Iordania a profitat și a ocupat Cisiordania (West Bank) și Egiptul a ocupat Fâșia Gaza. Mai mult, Ierusalimul era acum împărțit între forțele israeliene din vest și forțele iordaniene din est. A urmat apoi „Războiul de șapte zile” din 1967, în urma căruia Israelul a ocupat Ierusalimul de Est și Cisiordania, precum și majoritatea teritoriului Înălțimilor Golan siriene, Fâșia Gaza și peninsula egipteană Sinai. În figura nr. 2 este prezentată evoluția frontierelor Palestinei istorice în această perioadă (pe timpul mandatului britanic, conform planului de împărțire între cele două state și după cuceririle israeliene în urma războiului din 1967).

Cele două războaie arabo-israeliene au determinat plecarea, începând cu 1948, a aproximativ 700.000 de arabi palestinieni din teritoriul care a devenit statul Israel, către statele învecinate (în special în Cisiordania, Libia, Siria, Egipt) ${ }^{21}$, respectiv, din 1967, a 280.000 - 360.000 de arabi palestinieni din Cisiordania, Fâșia Gaza și Înălțimile Golan ${ }^{22}$. În același timp, pe fondul acelorași războaie, a avut loc exodul a aproximativ 860.000 de evrei din țările arabe, dintre care mai mult de 600.000 au ajuns în Israel, restul preferând Europa sau America ${ }^{23}$.

În 1973, a urmat cel de-al treilea război declanșat de forţele egiptene şi siriene împotriva Israelului, chiar de sărbătoarea evreiască Yom Kippur, sperând că vor recâştiga teritoriile pierdute în urma războiului din 1967. Forțele musulmane au fost sprijinite militar de Irak, Iordania, Arabia Saudită, Algeria, Cuba, Maroc şi Libia $^{24}$. Conflictul armat s-a finalizat cu semnarea, în 4 septembrie 1975, la Geneva, a unui acord egipteano-israelian care prevedea retragerea trupelor israeliene înapoi

${ }^{21}$ Colin Chapman, Kate Benson, Whose Promised Land: The Continuing Conflict Over Israel and Palestine, Lion Hudson, Oxford, England, 2015, p. 151.

${ }^{22}$ Antonio Carnovale, The Middle East: Everything That You Always Wanted to Know and No One Would Tell You, Universe LLC, Bloomington, USA, 2013, p. 126.

${ }^{23}$ Carole Basri, "The Jewish Refugees from Arab Countries: An Examination of Legal Rights - A Case Study of the Human Rights Violations of Iraqi Jews", în Fordham International Law Journal, Volume 26, Issue 32002 , p. 659.

${ }^{24}$ Stan Alexandru Bogdan, „Războiul de Yom Kippur - Armaghedonul din 1973”, Historia, URL: https://www.historia.ro/ sectiune/general/articol/razboiul-de-yom-kippur-armaghedonul-din-anul1973, accesat la 17.06.2021. 
din zonă cu câțiva kilometrii ${ }^{25}$. Totuşi, Israelul încă mai controla $2 / 3$ din Peninsula Sinai. Ulterior, în 1978, la Camp David, s-a semnat un tratat de către președinții Egiptului și Israelului, încheiat cu ajutorul medierii președintelui american din acea perioadă, Jimmy Carter, care prevedea normalizarea relațiilor dintre cele două state, după returnarea Peninsulei Sinai către Egipt ${ }^{26}$. În urma semnării acestor acorduri, Egiptul a fost exclus pentru 10 ani din Liga Arabă.

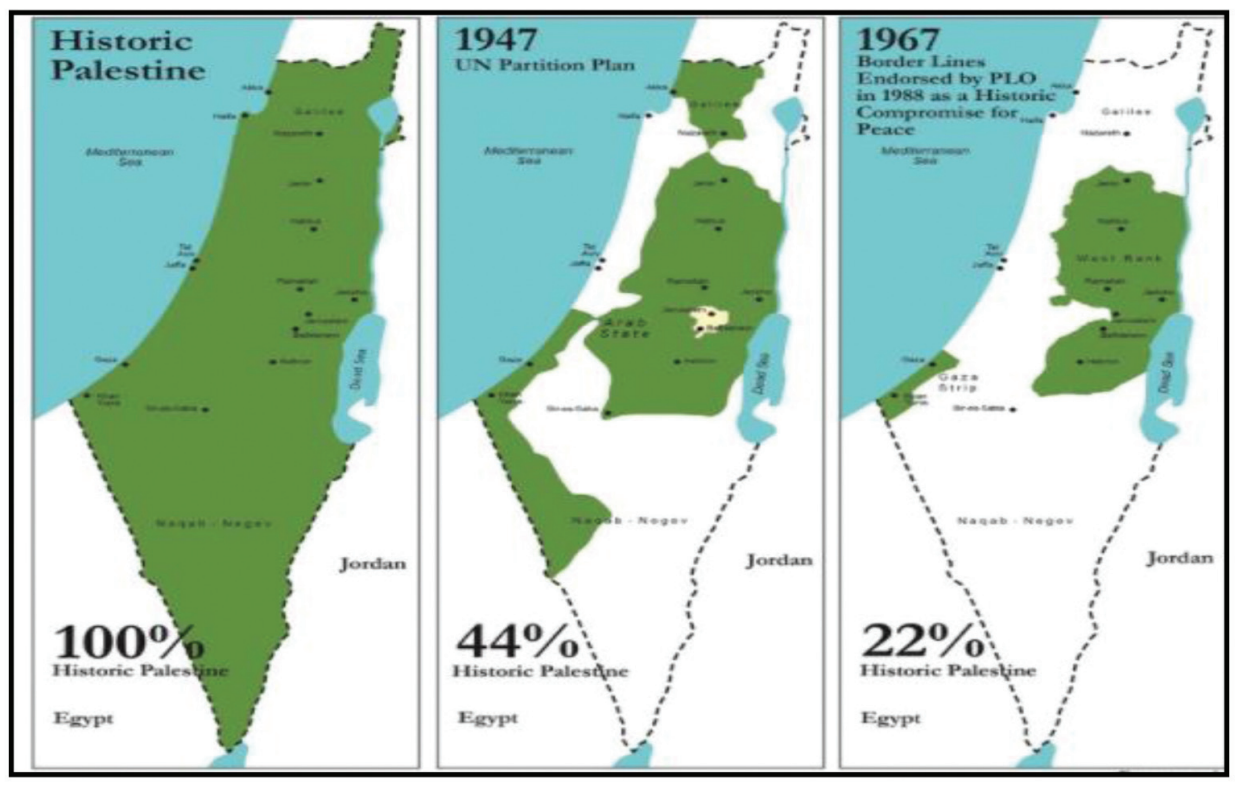

Figura nr. 2: Evoluţia frontierelor teritoriului istoric al Palestinei ${ }^{27}$

Așadar, rezultatul imediat al autodeclarării Israelului drept stat a fost desfășurarea șirului celor trei războaie majore arabo-israeliene $(1948-1949,1967,1973)$ prezentate mai sus, dar și a altor conflicte de mai mică intensitate (1956 - Criza Suezului, 1982 - primul război libanez, 2006 - al doilea război libanez), toate acestea reprezentând conflicte deschise care au implicat forțe militare din afara teritoriului Palestinei. Dar, pe termen lung, disputa politică dintre statele arabe și Israel a avut drept consecință nerecunoașterea de către o parte a acestora a legitimităţii și suveranităţii Israelului, aceste state considerând că pământurile ocupate de Israel prin forță militară aparțineau

$25 * * *$, Interim Agreement between Israel and Egypt, 4 septembrie, 1975.

26 ***, The Camp David Accords The Framework for Peace in the Middle East, 17 septembrie, 1978, URL: https://www.peaceau.org/uploads/camp-david-accords-egypt-1978.pdf, accesat la 20.06.2021.

$27 * * *$, ,Mapping Apartheid: 6 Digital Initiatives Reclaiming The Palestinian Map”, Scene Arabia, 16 martie 2020, URL: https://scenearabia.com/Life/Mapping-Apartheid-6-Digital-InitiativesReclaiming-the-Palestinian-Map?M=True, accesat la 02.06.2021. 
arabilor palestinieni. Totuși, au existat state arabe care au folosit această pârghie diplomatică în favoarea ascensiunii lor politice. De exemplu, imediat după primul război arabo-israelian, Iranul recunoștea Israelul în 1950, recunoaștere retrasă ulterior ca urmare a fricțiunilor dintre cele două state, amplificate pe seama luptei pentru supremație regională. Ulterior, Egiptul (1978) și Iordania (1994) au semnat acorduri de pace cu Israelul și au stabilit relaţii diplomatice cu acesta, acțiuni determinate de interese naționale: Egiptul a recâștigat peninsula Sinai de la Israel, iar Iordania a cedat ca urmare a stimulentelor economice și comerciale acordate de Israel și SUA. Omanul și Qatarul au recunoscut Israelul în 1996, dar ulterior și-au retras declarația din spirit de solidaritate cu ceilalți membri ai Ligii Arabe care, în 2002, la propunerea Arabiei Saudite, prin Inițiativa Arabă de Pace, promitea Israelului legături diplomatice depline cu întreaga lume musulmană în schimbul înființării unui stat palestinian între frontierele din 1967, cu capitala în Ierusalimul de $\mathrm{Est}^{28}$, promisiune care a fost reiterată la Summiturile Ligii din 2007 și 2017.

Un factor cheie în evoluția situației palestiniene a fost implicarea continuă a SUA în Orientul Mijlociu. Cea mai recentă implicare datează din perioada mandatului președintelui american Donald Trump (2017-2020), când au fost luate o serie de decizii de susținere evidentă a aliatului său strategic Israel, în detrimentul palestinienilor. Printre acestea s-au numărat ${ }^{29}$ : recunoașterea, în 2017, a Ierusalimului ca fiind capitala statului Israel și relocarea ambasadei americane din Tel Aviv la Ierusalim; acceptarea legală, în 2019, a așezărilor israeliene în teritoriile palestiniene (Cisiordania) şi recunoașterea Înălțimilor Golan ca parte a Israelului, în detrimentul Siriei; declararea, în 2020, a mişcării Boicot, Dezinvestire, Sancțiune - BDS (fondată pentru contestarea politicilor israeliene și sprijinirea independenței palestiniene), ca fiind antisemită; anunțarea planului soluției cu două state, cu prezentarea opțiunii ca Israelul să anexeze teritoriile Cisiordaniei. Aceste decizii americane evidente de susținere a statului evreu au determinat Autoritatea Națională Palestiniană (ANP) să suspende, în mai 2020, coordonarea administrativă și de securitate cu Israelul, inclusiv eliberarea permiselor de călătorie. De asemenea, luptele dintre Israel și grupurile armate palestiniene au continuat în special în Fâsșia Gaza. Totuși, ca urmare a negocierilor mediate de SUA, Emiratele Arab Unite (EAU) și Bahrain au reluat relațiile cu statul evreu în 2020, pe baza acordurilor Abraham, iar Autoritatea Națională Palestiniană din Cisiordania ocupată, ca reacție de protest, și-a rechemat ambasadorii din cele două state arabe ${ }^{30}$ și a renunțat la

28 ***, Beirut Declaration on Saudi Peace Initiative, The Arab Peace Initiative, 28 martie 2002.

${ }^{29}$ Mirela Atanasiu, „Dinamica conflictualității Orientului Mijlociu și Africii de Nord în pandemie”, în Dinamica mediului de securitate 2020. Securitatea, între pandemie și competiție, Editura Universitătii Naționale de Apărare „Carol I”, București, 2021, pp. 95-122.

30 ***, ,Arab normalisation with Israel in 500 words”, Al Jazeera, 23 noiembrie 2020, URL: https:// www.aljazeera.com/ news/2020/11/23/the-normalisation-of-ties-between-israel-and-arab-countries, accesat la 12.03.2021. 
președinția reuniunilor Ligii Arabe, atunci când organizația a refuzat să sancționeze decizia celor două state de a relua legăturile cu Israelul. Reacția ANP, în pofida condiției explicite impuse de cele două ca statul evreu ,să se abțină de la orice anexare a teritoriilor din Cisiordania"31, este datorată formulării mai puțin fermă, comparativ, de exemplu, cu cea susținută de ministrul de externe saudit care declara, în decembrie 2020, că „Arabia Saudită rămâne deschisă pentru a normaliza pe deplin legăturile cu Israelul, cu condiția statalității palestiniene"32, care arată clar că saudiții se țin de linia politică stabilită prin Inițiativa Arabă de Pace, nelăsând loc de interpretări sau compromisuri politice. De altfel, la sfârșitul anului 2020, printre statele arabe ale Orientului Mijlociu care erau prezentate ca nerecunoscând Israelul se mai numărau doar Siria, Yemen, Iran, Irak, Kuweit, Oman, Liban, Qatar și Arabia Saudită ${ }^{33}$. Așadar, oscilațiile în poziţionările politice ale celor 20 de state ale Ligii Arabe care au semnat Inițiativa Arabă de Pace sunt evidente - există state care susțin cu putere acceptarea statului palestinian de către Israel și state care au renunțat la susținerea cauzei palestiniene când a apărut posibilitatea obținerii unui interes național propriu.

A doua manifestare a conflictualității în Palestina este disputa arab̆ palestiniano-israeliană declanșată odată cu apariţia unei identități palestiniene a arabilor din teritoriul Palestinei istorice. Această identitate a început a se afirma inclusiv în Israel, în special în teritoriile ocupate de acesta în urma războiului arabo-israelian din 1967 (Ierusalimul de Est, Cisiordania, Fâșia Gaza). Conflictul palestiniano-israelian a provenit din incapacitatea de a determina suveranitatea asupra teritoriilor palestiniene care includ Ierusalimul de Est, Fâsșia Gaza și Cisiordania.

În 1974, comunitatea internațională (ONU, Liga Arabă și Organizaţia pentru Cooperare Islamică) a recunoscut Organizația pentru Eliberarea Palestinei (OEP) ca reprezentant legitim al poporului arab palestinian din aceste teritorii, iar în Acordurile de la Camp David din 1978 se recunoștea existența acestei identități etnice, specificându-se, în cuprinsul documentelor, că termenul „palestinieni” sau „poporul palestinian” se referă, de fapt, la ,arabii palestinieni” ${ }^{34}$. Ulterior, OEP a

\footnotetext{
${ }^{31}$ Kenneth Stein, Israel and Arab-Israeli Conflict Timeline - 1800s to the Present, Center for Israel Education, 26 ianuarie 2021, URL: https://israeled.org/israel-and-arab-israeli-conflict-timeline1800s-to-the-present/, accesat la 14.03.2021.

${ }^{32}$ Lauren Holtmeier, „Saudi Arabia open to full ties with Israel, on condition of Palestine state: Saudi FM", Al Arabiya, 5 decembrie 2020, URL: https://english.alarabiya.net/News/gulf/2020/12/05/ Saudi-Arabia-open-to-full-ties-with-Israel-on-condition-of-Palestine-state-Saudi-FM， accesat la 25.06.2021.

33 ***, „Israel International Relations: International Recognition of Israel”, Jewish Virtual Library, URL: https://www.jewishvirtuallibrary.org/international-recognition-of-israel, accesat la 25.06.2021.

34 ***, The Camp David Accords The Framework for Peace in the Middle East, op. cit., p. 14.
} 
proclamat independența statului Palestina în 1988 (în prezent, statul Palestina este recunoscut de 139 de state ale comunității internaţionale ${ }^{35}$ ).

În urma încheierii Acordurilor de la Oslo (Declarația de principii privind aranjamentele interimare de auto-guvernare) între Israel și Organizația pentru Eliberarea Palestinei la Washington, în 1993, după luni de negocieri secrete ${ }^{36}$, ocazie cu care a fost înființată Autoritatea Națională Palestiniană ca organism guvernamental interimar pentru perioada 1993-1999 și cele două entități statale își recunoșteau reciproc dreptul la existență ${ }^{37}$. Conform Acordurilor, controlul asupra afacerilor civile și de securitate în părți din Cisiordania și Fâșia Gaza au fost transferate către ANP. Ulterior, în 1994 a început procesul de construire a statului palestinian în cadrul procesului de pace din Orientul Mijlociu. Toate aceste iniţiative palestiniene de înaintare către o formă de obținere a statalității în acest teritoriu au stârnit nemulțumirea Israelului, situația transformându-se într-un conflict violent îndelungat.

Acest conflict, deși cu o dimensiune politică accentuată, fiind în primul rând o dispută între două națiuni pentru a-și legitima prevalența statală într-un teritoriu comun, are și o dimensiune umanitară externă. În prezent, în lume există patru milioane refugiați palestinieni care sunt apatrizi, mulți dintre ei în Liban, Siria și Iordania, Egipt, Libia, alte părți ale lumii arabe sau ale Golfului, ca și în Europa, America de Nord, Australia etc. ${ }^{38}$ Această situație persistă, deși Comisia pentru Concilierea Palestinei a fost înființată încă din 1949 pentru a sprijini părțile în a ajunge la o soluție politică cu privire la drepturile refugiaților palestinieni (de primă generație sau urmași ai acestora) de a se întoarce și a reintra în proprietatea bunurilor lor lăsate în Palestina. Există, de asemenea, o dimensiune umanitară internă a conflictului israeliano-palestinian care se manifestă prin faptul că palestinienilor li se refuză drepturi civile, politice și economice și sunt supuși discriminării sistematice și negării libertății și demnității de bază, așa cum s-a prezentat de multe ori în rapoartele emise de Oficiul Înaltului Comisar al Națiunilor Unite pentru Drepturile Omului ${ }^{39}$.

$35 * * *$, ,Diplomatic Relations”, Permanent Observer Mission of the State of Palestine to the United Nations, New York, URL: https://palestineun.org/about-palestine/diplomatic-relations/, accesat la 25.06.2021.

$36 * * *$, The Oslo Accords, 13 septembrie 1993.

$37 * * *$, Israel-PLO Mutual Recognition, Letters and Speeches, 10 septembrie 1993.

${ }^{38}$ Cindi Katz, Neil Smith, „An interview with Edward Said”, Environment and Planning D: Society and Space, volumul 21, 2003, p. 637, URL: https://journals.sagepub.com/doi/pdf/10.1068/d2106i, accesat la 18.06.2021.

${ }^{39}$ Exemple de astfel de rapoarte: ***, A/71/355, Israeli settlements in the Occupied Palestinian Territory, including East Jerusalem, and the occupied Syrian Golan, Report of the Secretary-General, UN General Assembly, 24 August 2016; ***, A/71/364, Israeli practices affecting the human rights of the Palestinian people in the Occupied Palestinian Territory, including East Jerusalem, Report of the Secretary-General, UN General Assembly, 30 August 2016. 
Dimensiunea militară a conflictului israeliano-palestinian s-a concentrat cel mai mult în Intifade, care au constat în proteste și revolte ale palestinienilor desfășurate în special pe teritoriile ocupate, dar și pe întreg teritoriul Israelului: prima, decembrie 1987-1993, a fost declanșată ca urmare a ocupației israeliene în Cisiordania (inclusiv a Ierusalimului de Est) și Gaza; a doua, septembrie 2000-2005, a fost declanșată ca urmare a înăspririi condițiilor de viaţă ale palestinienilor în teritoriile aflate sub ocupație (deportări, demolarea caselor, pedeapsa colectivă, stare de asediu, suprimarea instituțiilor politice $)^{40}$. Acestor Intifade, armata israeliană le-a răspuns în forță. Referitor la prima Intifadă, organizația Human Rights Watch arăta că, în primele 31 de luni forțele de securitate israeliene au ucis peste 670 de palestinieni și au rănit încă multe mii ${ }^{41}$.

Lupta revoluționară dusă de palestinieni s-a concretizat în principal în activitatea a două mișcări palestiniene care domină în teritoriile ocupate israeliene: Fatah - fosta Mișcare de eliberare națională a Palestinei -, partid politic socialdemocrat naționalist, parte a Organizației pentru Eliberarea Palestinei, avându-1 ca membru pe președintele Autorității Palestiniene Mahmoud Abbas și Hamas mișcare radicală islamică sprijinită de Iran. Fiecare dintre acestea luptă cu mijloacele militare avute la dispoziție împotriva ocupației Israelului, dar, din punct de vedere politic, sunt rivale și între ele. Separarea politică formală între Hamas și Fatah datează din iunie 2007, când Milițiile Hamas au preluat Fâșia Gaza după atacarea forțelor de securitate ale Autorității Palestiniene condusă de Fatah. Această separare a dus la înfiinţarea, prin decret prezidenţial, a unui guvern interimar în Cisiordania, iar Hamas și-a păstrat propriul guvern în $\mathrm{Gaza}^{42}$. În prezent, fiecare deține monopol asupra forței în zona sa de control.

Uneori, o formă mai acută a violenței politice a fost exprimată în conflict. De exemplu, Federația Oamenilor de Știință Americani prezintă că, în anii '70 mai multe grupuri afiliate OEP au efectuat atacuri teroriste internaționale, dar, ulterior, sub presiunea internațională, Fatah/OEP declara că va restricționa atacurile asupra Israelului și teritoriilor ocupate. Totuși, atacuri teroriste s-au mai înregistrat ulterior, fiind efectuate de grupuri afiliate cu Fatah împotriva țintelor din interiorul și din afara Israelului. ${ }^{43}$ În ceea ce privește Hamas, conform unuia dintre scopurile sale

\footnotetext{
${ }^{40}$ Mark Tessler, A History of the Israeli-Palestinian conflict, Indiana University Press, US, 1994, p. 677.

$41 * * *$, „The Israeli Army and the Intifada Policies that Contribute to the Killings”, Human Rights Watch Report, August 1990, URL: https://www.hrw.org/legacy/campaigns/israel/intifada-intro.htm, accesat la 19.06.2021.

${ }^{42}$ Margret Johannsen (coord.), „The Reconciliation of Hamas and Fatah Smoothing the Way to the Middle East Conference by Contributing to Peace and Security in the Region", Policy brief for the Middle East Conference on a WMD/DVS free zone, nr. 3, decembrie 2011, p. 1.

$43 * * *$, Palestine Liberation Organization (PLO), Federation of American Scientists, URL: https:// fas.org/irp/world/para/ plo.htm, , accesat la 19.06.2021.
} 
declarate în Carta sa organizațională - distrugerea Israelului ${ }^{44}$ (stat recunoscut de mare parte din comunitatea internațională) -, era considerată organizație teroristă de comunitate largă (Hamas este încă desemnată ca fiind organizaţie teroristă de către Israel, SUA, UE, Japonia și Canada), dar faptul că și-a folosit serviciile sociale pentru a sprijini arabii din Palestina, i-a dat legitimitate din partea populației autohtone. După 2017, când a emis un nou document de principiu al organizației ${ }^{45}$ din care formulările radicale au fost eliminate și pe fondul faptului că a luptat și luptă pentru cauza constituirii unui stat (islamic) palestinian, Hamas a câștigat și simpatia unei părți a comunității internaționale, fiind văzută de aceștia drept organizație revoluționară și opțiune politică viitoare la guvernarea palestinienilor.

În ceea ce privește disputa religioasă, Palestina a fost scena unor confruntări violente între practicanții religiei mozaice și musulmani timp de 100 de ani. Motivația evreilor este că, pentru ei, Palestina reprezintă „Țara Promisă”, Israelul fiind singura țară din lume în care aceștia formează majoritatea populației, iar pentru musulmanii fundamentaliști întreaga Palestina istorică trebuie să fie sub stăpânire islamică. Ierusalimul, de asemenea, găzduiește lăcașe sfinte ale creștinilor, musulmanilor și evreilor, deopotrivă, fiind reclamat drept capitală de ambele state, israelian sau palestinian, iar pentru creștini reprezintă „Orașul Sfânt”, locul în care s-a născut Iisus Christos. De altfel, Ierusalimul are 1200 de sinagogi și peste 150 de biserici derivate din cele 17 confesiuni creștine ${ }^{46}$ și 73 moschei $^{47}$. Părțile își justifică cerințele aducând, ca dovezi istorice ale dreptului lor de preempțiune asupra teritoriului istoric al Palestinei, interpretări ale Bibliei, Talmudului și/sau Coranului. De aceea, faptul că Parlamentul israelian a declarat ,întregul Ierusalim ca fiind capitala indivizibilă a Israelului’"48 a avut dublă consecință care a stârnit nemulțumire în regiune. Pe de o parte, o capitală, indiferent unde este așezată reconfirmă existența unui stat, decizia Israelului contravenind politicii statelor arabe care neagă legitimitatea ca stat a Israelului și, pe de altă parte, stabilirea capitalei

44 ***, The Charter of Allah: The Platform of the Islamic Resistance Movement (Hamas), translated and annotated by Raphael Israeli, Harry Truman Research Institute, The Hebrew University, Jerusalem, Israel, URL: https://fas.org/irp/world/ para/docs/880818.htm, accesat la 19.06.2021.

45 ***, Hamas: General Principles and Policies, Jewish Virtual Library, 2017, URL: https://www. jewishvirtuallibrary.org/ hamas-2017-document-of-general-principles-and-policies, accesat la 19.06.2021.

$46 * * *$, ,What Is The Holy City Of Christianity?”, The World Atlas, URL: https://www.worldatlas. com/articles/what-is-the-holy-city-of-christianity.html, accesat la 19.06.2021.

$47 * * *$, Behind the Headlines: Facts and Figures - Islam in Israel, Ministry of Foreign Affairs, Israel, 9 iunie 2016, URL: https://mfa.gov.il/MFA/ForeignPolicy/Issues/Pages/Facts-and-Figures-Islam-inIsrael.aspx, accesat la 19.06.2021.

48 ***, „Cui îi aparține Orașul Sfânt? Șase întrebări despre statutul Ierusalimului”, Deutche Welle, 06.12.2017, URL: https://www.dw.com/ro/cui-\%C3\%AEi-apar\%C8\%9Bine-ora\%C8\%99ulsf $\% C 3 \% A 2 n t-\% C 8 \% 99$ ase- $\% C 3 \% A E n t r e b \% C 4 \quad \% 83$ ri-despre-statutul-ierusalimului/a-41678762, accesat la 19.06.2021. 
la Ierusalim statuează prevalența religiei mozaice în detrimentul celorlalte religii. Decizia Israelului, deși neagreată de comunitatea internațională, a declanșat noi tensiuni etnico-religioase în epoca modernă între musulmani (arabi sau de alte etnii), evrei (israelieni sau palestinieni), dar și creștini, indiferent dacă sunt din Israel sau teritoriile ocupate de acesta.

Pe acest fond al tensiunilor religioase, în teritoriile ocupate se desfăşoară violențe comunitare între etnicii palestinieni arabi și creștini, pe de o parte, și evrei, de cealaltă parte, unele desfășurate violent, cu ajutorul armelor de foc sau a dispozitivelor explozive improvizate. De asemenea, deși există acești factori religioși relevanți pentru islam, creștinism și iudaism, care dictează rolul religiei ca principal factor al conflictului în regiune, această latură a conflictului a trecut în plan secund în perioada recentă, accentul fiind trecut pe conflictul din interiorul Israelului, desfășurat în teritoriile ocupate locuite de palestinieni. Mai mult, indiferent dacă este considerată ,,arabă” sau ,islamică”, problema nerezolvată a Palestinei deține un loc important în dezvoltarea curentelor naționalismului arab și a Islamului politic, ambele relaționate cu apariția mișcărilor extremiste precum Hamas care, sub imboldul religios, devin un model de insecuritate în regiune.

\section{Problema palestiniană în primul semestru al anului 2021 şi tendințe de evoluție}

În prezent, Israelul încă ocupă Cisiordania, deși a ieșit din Fâșia Gaza în 2005, ONU considerând-o încă parte a teritoriului ocupat, deoarece Israelul păstrează controlul militar deplin asupra acesteia, gestionându-i granițele și spațiul aerian, restricționând ceea ce este permis în interior și în exterior și angajându-se periodic în teritoriu, cu forțe armate. De asemenea, Israelul revendică întregul Ierusalim ca fiind capitala sa, în timp ce palestinienii revendică Ierusalimul de Est drept capitala unui viitor stat palestinian. Guvernul Fatah din Cisiordania este singurul reprezentant al statului Palestina recunoscut internațional, de aceea acesta se referă la Fâșia Gaza ca parte a statului palestinian și nu recunoaște guvernul Hamas. Totuși, cele două, Fatah și Hamas, au ajuns la un acord prin care să se permită organizarea de alegeri prezidențiale palestiniene în comun, care să permită conducerea statului palestinian compus din cele două teritorii ocupate de un singur președinte.

Fâșia Gaza are o populație de aproximativ 2,1 milioane de oameni, inclusiv aproximativ 1,4 milioane de refugiați palestinieni și o situație socio-economică în declin constant ${ }^{49}$. Problema principală care necesită rezolvare urgent este cea umanitară, decurgând din faptul că în Gaza aproximativ $80 \%$ din populația sa depinde de ajutorul internațional și aproximativ un milion de oameni se bazează

49 ***, „Gaza Strip”, United Nations Relief and Works Agency for Palestine Refugees in the Near East, 2021, URL: https://www.unrwa.org/where-we-work/gaza-strip, accesat la 20.06.2021. 
pe ajutorul alimentar zilnic ${ }^{50}$. De altfel, în 2020, rata medie a șomajului se apropia de 50\%, una dintre cele mai mari din lume, tendința fiind de înrăutătire în 2021. Problemele socio-economice sunt legate și de accesul la apă curată și electricitate, care rămâne la nivel de criză, apa curată este disponibilă pentru o marjă mică din populație, iar energia electrică este livrată doar câteva ore pe zi, ceea ce afectează negativ toate celelalte servicii esenţiale, în special pe cele de sănătate și salubrizare, dar și sectoarele producției și agriculturii din Gaza. Mai mult, blocada impusă de Israel, pe uscat, aer și mare, în urma preluării de către Hamas a Fâșiei Gaza în 2007, continuă să aibă un efect devastator din cauza faptului că mișcarea populației către și dinspre Fâșia Gaza, precum și accesul la piețe, rămân sever restricționate. Această situație persistă deși, la nivelul comunității internaționale (în special al ONU), s-a constatat că blocada și restricțiile aferente acesteia contravin dreptului umanitar internațional, prin dificultăţile provocate populației civile.

În Cisiordania, între 2,1 și 3 milioane arabi palestinieni se află atât sub autoguvernare limitată, cât și sub conducerea militară israeliană, alături de aproximativ 430.000 de evrei israelieni care trăiesc în 132 de aşezări (și 124 de „avanposturi” mai mici) construite sub ocupația Israelului ${ }^{51}$. Dar, dintre aceștia, 900.000 de palestinieni aflați într-o zonă controlată de Israel (inclusiv Ierusalimul de Est) care se extinde la peste $60 \%$ din teritoriul acesteia, au acces limitat la apă, asistență medicală, educație și alte servicii critice. Potrivit Biroului Comisiei Europene Ajutor Umanitar (ECHO), din cauza violenței, intimidării și neacordării autorizațiilor de construcție, populația palestiniană este din ce în ce mai supusă evacuărilor forțate și își vede casele și infrastructura demolate, acțiuni care s-au intensificat în ciuda pandemiei, palestinienii fiind separați de pământul și familiile lor, precum și de școli, spitale, locuri de muncă și lăcașuri de cult ${ }^{52}$.

Începutul anului 2021 găsește teritoriile ocupate într-un mediu tensionat, cu escaladări violente intermitente, marcate prin lansări de rachete și lovituri aeriene. De exemplu, în 18-19 ianuarie, trei rachete au fost lansate din Gaza, în sudul Israelului, acțiune urmată de atacuri aeriene israeliene ${ }^{53}$. De asemenea, în cel puțin 84 de ocazii, forțele israeliene au deschis foc de avertizare către palestinieni în apropierea gardului construit de Israel și în afara coastei maritime a Fâșiei Gaza, ceea ce reprezintă o creștere a acțiunilor conflictuale cu aproximativ $14 \%$, comparativ cu media lunară a

\footnotetext{
$50 * * *$, „Israel-Palestinian conflict: Life in the Gaza Strip”, BBC News, 20 mai 2021, URL: https:// www.bbc.com/news/ world-middle-east-20415675, accesat la 21.06.2021.

$51 * * *$, „Explainer: Israel, annexation and the West Bank”, BBC News, 25 iunie 2020, URL: https:// www.bbc.com/news/ world-middle-east-52756427, accesat la 18.06.2021.

52 ***, „Palestine”, European Civil Protection and Humanitarian Aid Operations, European Commission, 17/11/2020, p. 1, URL: https://reliefweb.int/sites/reliefweb.int/files/resources/ palestine_2020-11-18.pdf, accesat la 18.06.2021.

53 ***, Gaza Strip: Snapshot - January 2021, OCHA, 2021, URL: https://reliefweb.int/sites/reliefweb. int/files/resources/gaza_snapshot_january_2021.pdf, accesat la 20.06.2021.
} 
acestor incidente înregistrate în $2020^{54}$. Astfel de acțiuni au persistat și în următoarele luni, totuși, violențele menținându-se la intensitate relativ scăzută. Mai mult, unii oficiali ai ONU erau optimiști, susținând că alegerile israeliene și palestiniene care urmau să se desfășoare în 2021 ar putea deschide calea restaurării orizontului politic legitim în Orientul Mijlociu ${ }^{55}$. Dar, spre sfârșitul lunii aprilie 2021, pe fondul inițierii evacuării și confiscării proprietăților unor rezidenți palestinieni din Ierusalimul de Est, s-au acumulat tensiuni în Ierusalim, manifestate prin proteste și demonstrații civile desfăşurate atât de către palestinienii din Cisiordania, cât și din Gaza.

Un alt factor care a stârnit nemulțumirea populară în Cisiordania a fost restricționarea, de către forțele de securitate israeliene, a accesului și limitarea mișcării palestinienilor la moscheea Al-Aqsa ${ }^{56}$ din orașul vechi al Ierusalimului, în ultimele zile ale Ramazanului. Astfel, s-au declanşat demonstrații civile care au culminat cu ciocnirile din 7 mai, de la moschee, între palestinienii înarmați cu pietre și sticle incendiare și forțele israeliene care au folosit gaze lacrimogene, grenade și gloanțe de cauciuc, rezultând 25 de palestinieni uciși și 6.309 de răniți pe întregul teritoriu al Cisiordaniei, dintre care, în Ierusalimul de Est a fost cel puțin un palestinian ucis și 1.011 de răniți ${ }^{57}$.

Din Gaza, pe 10 mai, grupurile armate palestiniene au început să lanseze rachete spre zonele populate ale Israelului, după ce Hamas a emis un ultimatum forțelor israeliene pentru a se retrage din moscheea Al-Aqsa, iar acestea nu s-au conformat. Brigăzile al-Qassam, aripa militară a Hamas, au lansat rachete către Ierusalim ${ }^{58}$, armata israeliană ripostând cu rachete și artilerie, țintind zonele populate din Fâșia Gaza $^{59} . \mathrm{Cu}$ această ocazie, armata israeliană a declarat că a ucis un comandant de vârf al grupului armat al Jihadului Islamic, Hussam Abu Harbeed ${ }^{60}$. Potrivit

${ }^{54}$ Ibidem.

55 ***, SC/14453, Upcoming Israeli, Palestinian Elections Could Pave Way to Restoring Legitimate Political Horizon in Middle East, Top Official Tells Security Council, United Nations, 26 februarie 2021, URL: https://www.un.org/press/ en/2021/sc14453.doc.htm, accesat la 23.06.2021.

${ }^{56}$ N.A.: Al Aqsa este una dintre cele mai venerate locaţii ale Islamului, dar și cel mai sfânt loc din Iudaism. Detalii: ***, „Al-Aqsa mosque: Dozens hurt in Jerusalem clashes”, BBC News, 8 mai 2021, URL: https://www.bbc.com/news/world-middle-east-57034237, accesat la 23.06.2021.

57 ***, ,Escalation in the Gaza Strip, the West Bank, and Israel”, Situation Report No. 1, United Nations Population Fund, 13 aprilie - 20 mai, 2021, p. 2.

${ }^{58}$ Adnan Abu Amer, „How the Gaza war affected Palestinian politics”, Al Jazeera, 7 iunie 2021, URL: https:/www.aljazeera.com/opinions/2021/6/7/gaza-war-leaves-its-mark-on-the-palestinianpolitical-system, accesat la 20.06.2021.

59 ***, Q\&A: 2021 Hostilities between Israel and Palestinian Armed Groups, Human Rights Watch, 28 mai, 2021, URL: https://www.hrw.org/news/2021/05/28/qa-2021-hostilities-between-israel-andpalestinian-armed-groups, accesat la 22.06.2021.

${ }^{60}$ Virginia Pietromarchi, Usaid Siddiqui, ,Israel kills Islamic Jihad commander, Gaza death toll above 200", Al Jazeera, 17 mai 2021, URL: https://www.aljazeera.com/news/2021/5/17/israel-launchesheavier-raids-in-second-week-of-gaza-bombing, accesat la 23.06.2021. 
autorităților din Gaza, în urma confruntărilor militare care au avut loc între 10 și mai, cel puțin 219 palestinienii au fost uciși, dintre care cel puțin 63 de copii și 35 de femei și alte 1.570 de persoane au fost rănite ${ }^{61}$. Situaţia este cu atât mai gravă cu cât sistemul de sănătate din Gaza, deja copleșit de mulți ani de blocadă și de pandemia de COVID-19, este suprasolicitat.

Atacurile israeliene au provocat distrugerea și deteriorarea construcțiilor civile pe scară largă (clădiri guvernamentale, ansambluri rezidențiale, sedii de organizații umanitare internaționale, facilități medicale, birouri media și drumuri care leagă civili de servicii esențiale, cum ar fi spitale), acestea putând constitui atacuri nediscriminatorii și disproporţionate asupra civililor și a obiectelor civile, respectiv crime de război ${ }^{62}$. De altfel, doar între 13 aprilie și 17 mai, Organizația Mondială a Sănătății a raportat cel puțin 91 de atacuri împotriva unităților medicale din teritoriile ocupate palestiniene (70 în Cisiordania, inclusiv Ierusalimul de Est, și 21 în Fâșia Gaza) $)^{63}$. De altfel, situația de ansamblu a palestinienilor din Cisiordania, Ierusalimul de Est și Gaza s-a deteriorat semnificativ, ca urmare a escaladărilor în violență din luna mai 2021. În același timp, rachetele lansate de Hamas, grupul Jihad Islamic și alte grupuri palestiniene înarmate au ucis 10 cetățeni israelieni și rezidenți, inclusiv doi copii, și au forțat mii de israelieni să se refugieze în adăposturi ${ }^{64}$. Totuși, mare parte dintre rachetele trase de grupurile armate palestiniene au fost blocate de sistemul israelian de apărare antiaeriană.

După începerea raidurilor aeriene reciproce, Israelul, prin reprezentantul său la ONU, a trimis o scrisoare Consiliului de Securitate, în care invoca dreptul și datoria Israelului de a-și apăra poporul și suveranitatea și solicita comunității internaționale să-i susțină „dreptul fundamental la autoapărare". ${ }^{55} \mathrm{Pe}$ de altă parte, Palestina susținea că ,principiul autoapărării nu poate fi aplicat de Israel pentru el însuși pe teritoriul ocupat al statului Palestina" ${ }^{\prime 6}$. În urma acestei corespondențe, la 27 mai, Consiliul pentru Drepturile Omului a adoptat o rezoluție pentru asigurarea respectării dreptului internațional umanitar și drepturilor omului, care mandata

$61 * * *$, ,Escalation in the Gaza Strip, the West Bank, and Israel”, op. cit.

$62 * * *$, ,Statement by Michelle Bachelet UN High Commissioner for Human Rights”, Special Session of the Human Rights Council on the deteriorating human rights situation in the Occupied Palestinian Territory, including East Jerusalem, Geneva, 27 mai 2021.

$63 * * *$, ,Escalation in Occupied Palestinian Territory”, Issue 2, World Health Organization, 17 mai 2021, p. 1 .

64 ***, SC/14521, Senseless Cycle of Bloodshed, Destruction between Israel, Palestinians in Gaza Must Stop Now, Secretary-General Tells Security Council, UNSC, 16 mai 2021, URL: https://www. un.org/press/en/2021/sc14521.doc.htm, accesat la 22.06.2021.

$65 * * *, 21$ May 2021 - Letter on Article 51 - Self-Defense, Permanent Observer Mission of the State of Palestine to the United Nations, New York, 2021, URL: https://palestineun.org/21-may-2021letter-on-article-51-self-defense/, accesat la 24.06.2021.

${ }^{66}$ Ibidem. 
Consiliul pentru Drepturile Omului să înființeze, de urgență, o comisie de anchetă permanentă, independentă și internațională, care să investigheze, în teritoriul palestinian ocupat și în Israel, toate presupusele încălcări și abuzuri înregistrate, începând cu 13 aprilie 2021, pentru a putea identifica cauzele tensiunilor recurente dar și ale instabilității și prelungirii conflictului ${ }^{67}$.

Tensiunile au continuat și în luna iunie, deși într-o notă mai joasă, în pofida acordului de încetare a focului încheiat în 21 mai 2021 și a întâlnirii mediatorilor egipteni cu oficiali israelieni și Hamas pentru a încerca să susțină armistițiul dintre Israel și Hamas. De altfel, după o perioadă mai calmă, în care forțele politice interne ale Israelului au fost preocupate mai mult de acțiunile de îndepărtare de la putere a prim-ministrului israelian Benjamin Netanyahu, la jumătatea lunii iunie, după schimbarea guvernării, Israelul a reluat atacurile aeriene în forță asupra Fâșiei Gaza, ca răspuns la baloanele incendiare trimise peste graniță de grupările armate palestiniene.

Tendințele identificate în ceea ce privește problema palestiniană la jumătatea anului 2021 sunt: stagnarea efortului politic depus de părți în direcția stabilirii statalității Palestinei; posibila dinamizare a efortului militar reciproc între Hamas și Israel; câștigarea unui capital de imagine al Hamas față de Fatah, care îi poate oferi un avantaj la alegerile prezidențiale cu viitor incert.

Stagnarea politică în procesul obținerii statalității Palestinei a apărut la momentul deciziei lui Mahmoud Abbas de amânare a alegerilor în teritoriile palestiniene, pe baza constatării că organizarea scrutinului în Ierusalimul de Est nu este facilitată de Israel. Dar, schimbarea administrației SUA, preluată de Joe Biden, ajungerea lui Isaac Herzog la președinția Israelului și înlocuirea fostului prim-ministru israelian Netanyahu, bănuit de corupție, cu Naftali Bennet, reprezintă factori care pot aduce atuuri în negocierile palestinienilor cu Israelul. $\mathrm{Cu}$ toate acestea, se menține riscul ca deciziile politicienilor nou împuterniciți, dacă vor fi luate hazardat sau partinic, pe fondul actual al menținerii conflictului dintre Hamas și Israel la o intensitate oscilantă, să prezinte pericolul unor noi escaladări violente, care să distrugă acordul de încetare a ostilităților, deja fragilizat de acțiunile recente. De altfel, în presa arabă se susține că Bennet este susținător al așezărilor evreiești și al anexării majorității Cisiordaniei, inclusiv a Ierusalimului de Est, și se opune unei soluții cu două state ${ }^{68}$. În studiile americane, președintele Biden este văzut drept susținător al soluției cu

${ }^{67} \mathrm{~A} / \mathrm{HRC} / 47 / 57$, Agenda item 7. Human rights situation in Palestine and other occupied Arab territories Report of the Special Rapporteur on the situation of human rights in the Palestinian territories occupied since 1967, Human Rights Council Forty seventh session, 21 iunie-9 iulie 2021, p. 3 .

${ }^{68}$ Anchal Vohra, „Will Israel's Bennett be worse than Bibi for Palestinians?”, Al Jazeera, 17 iunie 2021, URL: https://www.aljazeera.com/news/2021/6/17/will-bennett-be-worse-than-bibi, accesat la 20.06.2021. 
două state ca singură rezolvare viabilă a conflictului și căutând să reseteze relația cu conducerea palestiniană din Ramallah ${ }^{69}$, iar Herzog este prezentat de agențiile de știri că „optează pentru menținerea dialogului cu liderii palestinieni" ${ }^{70}$. Considerăm că, deși cvartetul pentru Orientul Mijlociu, compus din Uniunea Europeană, Federația Rusă, SUA și ONU, se concentrează asupra revenirii la negocieri care să ducă la o soluție cu două state în problema palestiniană, opoziția unui Israel care rămâne inflexibil și nesancționat de comunitatea internațională pentru încălcările legislației internaționale în relația cu palestinienii și lipsa unei unități politice între cele două guverne palestiniene din Cisiordania și Gaza reprezintă obstacole majore în această direcție.

În ceea ce privește câștigul de imagine al Hamas, acesta s-a realizat pe baza a două aspecte concrete. În Cisiordania, președintele Mahmoud Abbas a prelungit cu luni de zile starea de urgență decretată pentru COVID-19 care limita dreptul de mișcare al palestinienilor, ultima perioadă fiind stabilită până la începutul lunii iulie $2021^{71}$, deși situația medicală de ansamblu se ameliorase semnificativ, comparativ cu Gaza, unde Hamas a ușurat restricțiile pe măsură ce cazurile de îmbolnăvire cu SARS-CoV-2 au scăzut ca număr și intensitate. De asemenea, reacția lui Abbas, în urma intervențiilor forțelor armate israeliene la demonstrațiile organizate de palestinieni, care s-a limitat la discurs, a fost văzută ca fiind slabă și nepotrivită, de către opinia publică, unde populația a ieșit în stradă în solidaritate cu palestinienii din Ierusalim și Gaza. Mai mult, în acest context nemulțumiții au cerut încetarea „cooperării de securitate” a Autorității Palestiniene (AP) cu Israelul, unii dintre aceștia cântând imnuri pro-Hamas la demonstrații, iar forțele de securitate ale AP au intervenit și ele și au atacat protestatarii, arestându-i pe unii activiști ${ }^{72}$. Intervenția violentă a forțelor de securitate ale AP reprezintă un alt aspect pentru care Hamas, văzut deja ca sprijin prin raidurile asupra Israelului, de către populația ieșită la demonstrațiii, a câștigat capital de popularitate, obținând mai multe șanse de a prelua președinția teritoriilor palestiniene, dacă se va ajunge la un consens în ceea ce privește organizarea alegerilor prezidențiale.

\footnotetext{
${ }^{69}$ Hesham Youssef, „10 Things to Know: Biden's Approach to the Israeli-Palestinian Conflict”, United States Institute of Peace, 10 iunie, 2021, URL: https://www.usip.org/publications/2021/06/10-thingsknow-bidens-approach-israeli-palestinian-conflict, accesat la 20.06.2021.

${ }^{70}$ Gulsen Topcu, Israeli president pledges to maintain dialogue with Palestinian counterpart, Anadolu Agency, 12.07.2021, URL: https:/www.aa.com.tr/en/middle-east/israeli-president-pledgesto-maintain-dialogue-with-palestinian-counterpart/ 2301487, accesat la 20.06.2021.

71 ***, Coronavirus disease 2019 (COVID-19) Situation Report 77, World Health Organization, 17 iunie 2021.

${ }^{72}$ Adnan Abu Amer, art. cit.
} 


\section{Concluzii}

Pe de o parte, în istoria Palestinei, implicarea colonizatorilor occidentali, a sioniștilor și a țărilor arabe vecine a jucat un rol instrumental în modelarea cursului problemei palestiniene. Pe de altă parte, problema palestiniană setează dinamica regională constituind unul dintre principalii factori care modelează politica Orientului Mijlociu, aceasta datorându-se triplei sale manifestări conflictuale: problema arabo-israeliană, conflictul palestinian-israelian şi conflictul religios. Israelul este miezul conflictului multidimensional din Palestina, manifestat în cele trei conflicte existente. Împotriva Israelului se situează palestinienii, sprijiniți de lumea arabă, susținută, la rândul ei, de lumea musulmană. Israelul este susținut de SUA, încă de la constituirea sa ca stat. SUA au interese regionale legate în principal de securizarea surselor sale de energie și contracararea influenței Iranului și Rusiei, care au fost promovate cu succes de către Israel, de aceea, de cele mai multe ori de-a lungul timpului politica americană a înclinat în favoarea statului israelian, chiar când au fost încălcate drepturi fundamentale ale omului, ceea ce a dus la blocarea procesului de implementare a soluției cu două state sau măcar la înaintarea negocierilor israeliano-palestiniene.

Latura problemei palestiniene manifestată prin conflictul palestinian-israelian în interiorul teritoriilor ocupate este cea mai acută în momentul de față, conflictul religios și cel arabo-israelian trecând în plan secund ca nivel de intensitate. Această transgresiune s-a realizat în etape semnalizate de diferite perioade istorice, plecând de la conflictul intercomunitar (religios la bază) între evrei și arabi din perioada Mandatului britanic, accentul s-a mutat apoi pe dimensiunea etnică a dreptului palestinienilor la statalitate (la momentul constituirii statului Israel și izbucnirea conflictului interstatal marcat de cele trei războaie principale arabo-israeliene) și apoi, accentul a trecut pe dimensiunea politică marcată de dorința de delimitare a teritorialității între israelieni și arabii palestinieni.

În ceea ce privește teritoriile ocupate, la momentul actual, aici sunt prezente câteva probleme majore: divizarea politică în arena palestiniană între Hamas și Fatah; tensiunile de securitate dintre Hamas și Israel; modalitatea de înființare a Palestinei (ca stat de sine stătător sau ca entitate politică autonomă faţă de Israel), modul de reglementare a situației Ierusalimului și a evreilor care trăiesc în Gaza și Cisiordania (inclusiv Ierusalimul de Est).

Escaladarea conflictului, în mai 2021, a fost direct legată de răspunsul exagerat din partea forțelor de securitate israeliene la protestele organizate în Ierusalimul de Est la moscheea al-Aqsa, care s-au răspândit apoi pe întreg teritoriul palestinian ocupat și, de asemenea, în Israel.

Consecințele distrugerii fără discernământ, de către forțele aeriene israeliene, a infrastructurii palestiniene, în special a celor de apă, salubritate și electricitate, 
dar și medicale, vor provoca efecte sociale considerabile și prezente pe termen lung asupra populației din Gaza, adâncindu-se criza umanitară deja existentă și apărând riscul creșterii efectelor pandemiei. De altfel, acțiunile unilaterale ale actorilor implicați continuă să erodeze perspectiva unui stat palestinian viabil și contiguu, îndepărtând părțile de la un dialog constructiv și de la compromis.

După decenii de negocieri și iniţiative de pace eșuate, un prim pas spre pacificarea regiunii este acordarea de drepturi egale evreilor și palestinienilor arabi din Fâșia Gaza şi Cisiordania, precum și acordarea unui acces egal, în Ierusalim, reprezentanților tuturor religiilor care au lăcașe sfinte aici. În acest sens, SUA trebuie să facă o schimbare în tipul de politică dusă în problema palestiniană și să mute centrul de greutate de pe susținerea, cu prioritate, a partenerului său strategic, Israel, pe o abordare bazată pe drepturile egale dintre cele două părți. Un plus al unei astfel de abordări, pe baza implementării reale a respectării drepturilor etnicilor evrei și arabi din Palestina, este compatibil cu revigorarea soluției cu două state, în timp ce rămâne deschisă și către alte alternative politice.

\section{BIBLIOGRAFIE:}

1. ***, BBC News, URL: https://www.bbc.com/news

2. ***, ,Escalation in Occupied Palestinian Territory”, Issue 2, World Health Organization, 17 mai 2021.

3. ***, „Escalation in the Gaza Strip, the West Bank, and Israel”, Situation Report No. 1, United Nations Population Fund, 13 aprilie - 20 mai, 2021.

4. ***, „Human landscapes and maps”, Panorama of the world, 26 noiembrie 2017.

5. ***, ,Statement by Michelle Bachelet UN High Commissioner for Human Rights", Special Session of the Human Rights Council on the deteriorating human rights situation in the Occupied Palestinian Territory, including East Jerusalem, Geneva, 27 mai 2021.

6. $20 * * *$, ,The Israeli Army and the Intifada Policies that Contribute to the Killings", Human Rights Watch Report, Human Rights Watch, august 1990.

7. ***, 21 May 2021 -Letter on Article 51-Self-Defense, Permanent Observer Mission of the State of Palestine to the United Nations, New York, 2021.

8. ***, A/71/355, Israeli settlements in the Occupied Palestinian Territory, including East Jerusalem, and the occupied Syrian Golan, Report of the SecretaryGeneral, UN General Assembly, 24 august 2016.

9. ***, A/71/364, Israeli practices affecting the human rights of the Palestinian people in the Occupied Palestinian Territory, including East Jerusalem, Report of the Secretary-General, UN General Assembly, 30 august 2016. 
10. ***, A/HRC/47/57, Agenda item 7. Human rights situation in Palestine and other occupied Arab territories Report of the Special Rapporteur on the situation of human rights in the Palestinian territories occupied since 1967, Human Rights Council forty seventh session 21 iunie-9 iulie 2021.

11. ***, A/RES/181(II), Resolution adopted on the report of the ad hoc committee on the Palestinian question, UN General Assembly, 29 Noiembrie 1947.

12. ***, Beirut Declaration on Saudi Peace Initiative, The Arab Peace Initiative, 28 martie 2002.

13. ***, C. 529. M. 314. 1922. VI., Communiqué au Conseil et aux Membres de la Société, Mandate for Palestine, League of Nations, Geneve, 12 august 1922.

14. ***, ,Coronavirus disease 2019 (COVID-19) Situation Report 77”, World Health Organization, 17 iunie 2021.

15. ***, ,Gaza Strip: Snapshot - January 2021”, OCHA, 2021.

16. ***, Interim Agreement between Israel and Egypt, 4 septembrie 1975. 1993.

17. ***, Israel-PLO Mutual Recognition, Letters and Speeches, 10 septembrie

18. ***, Marea istorie ilustrată a lumii, vol. I, Editura Litera Internaţional, Bucureşti, 2008.

19. ***,,Q\&A: 2021 Hostilities between Israel and Palestinian Armed Groups”, Human Rights Watch, 28 mai, 2021, URL: https://www.hrw.org/news/2021/05/28/ qa-2021-hostilities-between-israel-and-palestinian-armed-groups

20. ***, ,SC/14453, Upcoming Israeli, Palestian Elections Could Pave Way to Restoring Legitimate Political Horizon in Middle East, Top Official Tells Security Counci'l, United Nations, 26 februarie 2021.

21. ***, ,SC/14521, Senseless Cycle of Bloodshed, Destruction between Israel, Palestinians in Gaza Must Stop Now, Secretary-General Tells Security Council", UNSC, 16 mai 2021.

22. ***, The Camp David Accords The Framework for Peace in the Middle East, 17 septembrie 1978.

23. ***, The Charter of Allah: The Platform of the Islamic Resistance Movement (Hamas), translated and annotated by Raphael Israeli, Harry Truman Research Institute, The Hebrew University, Jerusalem, Israel, f.a.

24. ***, The Oslo Accords, 13 septembrie 1993.

25. ATANASIU, Mirela, „Dinamica conflictualității Orientului Mijlociu și Africii de Nord în pandemie", în Dinamica mediului de securitate 2020. Securitatea, între pandemie și competiție, Editura Universității Naționale de Apărare „Carol I”, București, 2021.

26. BARBER, Malcolm, "The Challenge of State Building in the Twelfth Century: the Crusader States in Palestine and Syria", Reading Medieval Studies, 
XXXVI, University of Reading, 2010.

27. BASRI, Carole, „The Jewish Refugees from Arab Countries: An Examination of Legal Rights - A Case Study of the Human Rights Violations of Iraqi Jews", Fordham International Law Journal, volumul 26, nr. 3, 2002.

28. CARNOVALE, Antonio, The Middle East: Everything That You Always Wanted to Know and No One Would Tell You, Universe LLC, Bloomington, USA, 2013.

29. CASKEL, Werner, „The Bedouinisation of Arabia”, American Anthropologist, nr. 56, 1954.

30. CHAPMAN, Colin; BENSON, Kate; Whose Promised Land: The Continuing Conflict Over Israel and Palestine, Lion Hudson, Oxford, England, 2015.

31. FARIS, Nabih, ,Amin Palestine”, Britannica, 25 iunie 2021, URL: https:// www.britannica.com/place/Palestine.

32. JACOBSON, David, „When Palestine Meant Israel”, Biblical Archaeology Review, vol. 27, nr. 03, mai/iunie 2001.

33. JOHANNSEN, Margret (coord.), „The Reconciliation of Hamas and Fatah Smoothing the Way to the Middle East Conference by Contributing to Peace and Security in the Region", Policy brief for the Middle East Conference on a WMD/ DVS free zone, nr. 3, decembrie 2011.

34. KATZ, Cindi; SMITH, Neil, ,An interview with Edward Said”, Environment and Planning D: Society and Space, vol. 21, 2003.

35. KOLLONTAI, Pauline; YORE, Sue; KIM, Sebastian (eds.), The Role of Religion in Peacebuilding. Crossing the Boundaries of Prejudice and Distrust, Jessica Kinsley Publishers, London and Philadelphia, 2018.

36. MAEIR, Aren M., „The Philistines and Their Cities”, Bible Odyssey, URL: https://www.bibleodyssey.org/en/places/related-articles/philistines-and-their-cities

37. MASALHA, Nur, ,The Concept of Palestine: The Conception Of Palestine from the Late Bronze Age to the Modern Period", Journal of Holy Land and Palestine Studies, vol. 15, nr. 2, noivembrie 2016.

38. RODINSON, Maxime, Islam et capitalisme, Éditions du Seuil, Paris, 1966.

39. SHALOM, Alex; SHALOM, Stephen Rosskamm, „The Palestinian question", Harper's Magazine, decembrie 2001.

40. SHEN, Peidong; LAVI, Tal et all, „Reconstruction of Patrilineages and Matrilineages of Samaritans and Other Israeli Populations From Y-Chromosome and Mitochondrial DNA Sequence Variation", Human Mutation, nr. 24, Wiley-Liss Inc., 2004.

41. STEIN, Kenneth, Israel and Arab-Israeli Conflict Timeline - 1800s to the 
Present, Center for Israel Education, 26 ianuarie 2021.

42. TESSLER, Mark, A History of the Israeli-Palestinian conflict, Indiana University Press, US, 1994.

43. VON GRUNEBAUM, G.E., „The Nature of Arab Unity before Islam”, Arabica, nr. 10, 1963.

44. YOUSSEF, Hesham, „10 Things to Know: Biden's Approach to the IsraeliPalestinian Conflict", United States Institute of Peace, 10 iunie 2021. 